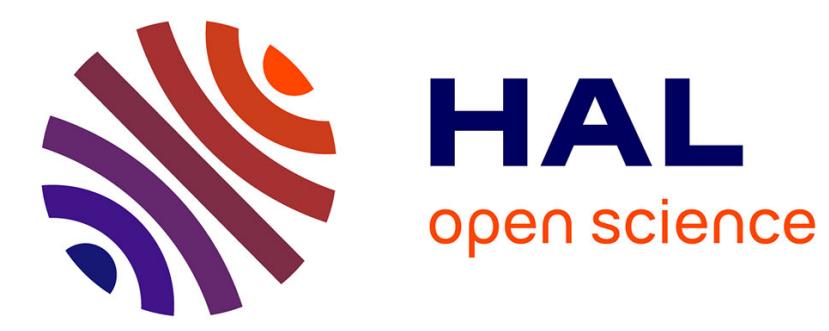

\title{
Ownership Structure and Bank Efficiency in the asia pacific region
}

Thierno Amadou Barry, Santos José O. Dacanay, Laetitia Lepetit, Amine Tarazi

\section{> To cite this version:}

Thierno Amadou Barry, Santos José O. Dacanay, Laetitia Lepetit, Amine Tarazi. Ownership Structure and Bank Efficiency in the asia pacific region. 2008. hal-00915134

\section{HAL Id: hal-00915134 \\ https://hal-unilim.archives-ouvertes.fr/hal-00915134}

Preprint submitted on 9 Dec 2013

HAL is a multi-disciplinary open access archive for the deposit and dissemination of scientific research documents, whether they are published or not. The documents may come from teaching and research institutions in France or abroad, or from public or private research centers.
L'archive ouverte pluridisciplinaire HAL, est destinée au dépôt et à la diffusion de documents scientifiques de niveau recherche, publiés ou non, émanant des établissements d'enseignement et de recherche français ou étrangers, des laboratoires publics ou privés. 


\title{
OWNERSHIP STRUCTURE AND BANK EFFICIENCY IN THE ASIA PACIFIC REGION
}

\author{
Thierno Amadou Barry ${ }^{\mathrm{a}^{*}}$, Santos Jose Dacanay III ${ }^{\mathrm{b}}$, Laetitia Lepetit ${ }^{\mathrm{a}}$, Amine Tarazi $^{\mathrm{a}}$
}

October 2008

\begin{abstract}
This paper focuses on efficiency measures of banks from six countries in East Asia. We use a two-stage approach to study the post-crisis period 1999-2004. We first estimate technical efficiencies using Data Envelopment Analysis and test for cross country differences. Efficiency scores are relatively high for South Korea and relatively low for the Philippines. We then investigate the link between ownership structure and efficiency controlling for various factors such as size, risk and the economic environment. We find that efficiency scores are higher for banks which are held by minority private shareholders and banks that are foreign-owned.
\end{abstract}

Keywords: Bank efficiency; ownership structure, DEA; East Asia Jel Classification : G21, G32

\footnotetext{
${ }^{a}$ Université de Limoges, LAPE, 5, rue Félix Eboué, 87031 Limoges, France ${ }^{\mathrm{b}}$ University of the Philippines, Institute of Management, 2600 Baguio City, Philippines *Corresponding author. Email: thierno.barry@unilim.fr This paper was prepared for the European Commission ASIA-LINK project B7-3010/2005/105-139: Safety and Soundness of the Financial System, coordinated by the University of Limoges. The contents of this paper are the sole responsibility of the authors and can under no circumstances be regarded as reflecting the position of the European Commission.
} 


\section{Introduction}

The financial crisis that hit Southeast Asia in 1997 raised various issues regarding the efficiency and the safety of local banking industries. After the crisis, bank regulators implemented several measures to reform the banking system with the aim of providing efficient banking services to the economy on a sustainable basis (Garcia, 1997). First, some governments decided to avoid closure of distressed banks by recapitalizing them. This process was accompanied by changes in management, ownership and governance. Second, Asian governments also avoided closure of banks by encouraging or even forcing safe banks to merge with distressed banks (Hawkins and Turner, 1999; Hawkins and Mihaljek, Gelos and Roldós, 2001; 2004). This consolidation process contributed to restore the financial viability of distressed banks even if it is not clear whether merging a weak bank and a strong bank, can actually create a strong bank (Hawkins and Turner, 1999). However, such interventions could still be more cost-effective than a government bailout or takeover. Third, Asian governments have facilitated the access of foreign investors in order to import international best practice and technological benefits (Choi and Clovutivat, 2004). Finally, many other restructuring processes were also implemented such as the replacement of underperforming bank managers and revision of managerial incentives.

This bank restructuring programme, which began almost immediately after the crisis in 1997 and which lasted until the early 2000s, modified the ownership structure and the governance of banks. This paper investigates the implications of such policies on the efficiency of commercial banks in East Asia during the post-crisis period 1999-2004. The countries examined in this paper are Hong Kong, Indonesia, South Korea, Malaysia, Philippines and Thailand. Except for Hong Kong, all these financial systems have long been dominated by commercial banks with extensive branch network which have been the most affected by the Asian financial crisis in 1997 (Laeven, 1999). Drake et al. (2006) however note that banks in Hong Kong also sharply suffered during the Asian financial crisis in 19971998 as it coincided with a local property market crash resulting in depressed profits and increased bad debts. Hence, the common experience of the six countries is a unique feature to assess the implications of the restructuring process that took place after the crisis.

Previous studies on emerging countries which have analyzed the impact of restructuring programs on bank efficiency do not provide conclusive results. Papers which have studied the relationship between foreign bank entry and efficiency in transition countries find mixed results (Claessens et al., 2001; Fries and Taci, 2002; Bonin et al., 2005). Unite and 
Sullivan (2003) show that foreign entry in the banking market in the Philippines corresponds to an improvement in operating efficiencies, but with a deterioration in the quality of loan portfolios. The studies which examine the link between bank ownership and efficiency, especially in transition economies, also provide mixed results (Grigorian and Manole, 2002; Yildrim and Philippatos, 2002; Fries and Taci, 2005; Bonin et al., 2005). For Asian countries, Laeven (1999) examines the risk factors and efficiency of banks using Data Envelopment Analysis, applied to the pre-crisis period 1992-1996 to predict which banks were restructured after the crisis of 1997. His findings show that state-owned and foreign-owned banks as well as Korean and Malaysian banks took little risk relative to other banks, while family-owned and company-owned banks and Indonesian and Philippine banks were among the highest risk takers. Williams and Nguyen (2005) focus on the link between bank performance and governance for five East Asian countries (Indonesia, South Korea, Malaysia, Philippines, and Thailand) between 1990 and 2003. Their findings show that, as a result of bank privatization programs, banks selected for domestic mergers and acquisitions (M\&As) exhibited relatively low rank order profit efficiency before the governance change, which improved in the short term but deteriorated in the long-term implying a temporary efficiency gain. Their results suggest that the benefits of domestic M\&As are realized in terms of technical developments, which determine productivity rather than managerial performance. They also find a considerable improvement in rank order technical change and productivity in the short term after M\&As, which was maintained in the long-term. On the whole their conclusions tend to support bank privatization and reject state ownership although their findings suggest that the potential benefits of foreign ownership may take a long time to be realized.

This paper extends the existing literature in three directions. First, the paper tests whether banks perform differently across countries during the post crisis period to focus on the implications of the restructuring process in the region. Our data therefore cover the 19992004 period. Second, we use a more detailed breakdown of bank ownership than in previous studies (that is state-owned, foreign-owned, private-owned, institutional investor-owned and widely-held). Third, two efficiency measures - technical efficiency and efficiency of revenue creation - are investigated in relation to bank characteristics such as ownership structure measures, size, risk indicators and environmental variables. We hence focus on efficiency measures consistent for institutions mainly involved in traditional intermediation activities (loans and deposits) but also on measures which capture more accurately expanded bank activities such as the provision of services (commission- and fee-based) and trading activities. 
The rest of the paper is structured as follows. Section 2 presents the methodology used to compute efficiency scores, as well as our dataset and the obtained results. Section 3 investigates the determinants of efficiency scores and section 4 concludes.

\section{Efficiency estimates}

\subsection{Method}

In this study, we use the Data Envelopment Analysis (DEA) with variable returns to scale (VRS) to compute efficiency scores. The choice of VRS over constant return to scale (CRS) is justified on the grounds that not all decision-making units (DMUs) are operating at an optimal scale due to imperfect competition and financial constraints. As we assume variable returns to scale, we can use two approaches to measure efficiency: the input-oriented (input minimization) approach and the output-oriented (revenue model) approach ${ }^{1}$. These two models will estimate exactly the same frontier and then by definition will identify the same set of efficient DMUs. But these two models will differ for the efficiency measures associated with the inefficient DMUs.

We use the intermediation approach in both input-oriented and output-oriented models. The intermediation approach, originally proposed by Sealey and Lindley (1977), is appropriate when banks operate as independent entities ${ }^{2}$ (Bos and Kool, 2006). Moreover, the intermediation approach which takes interest expenses into account may be more appropriate to evaluate financial institutions as they represent in general at least half of total costs (Berger and Humphrey, 1997).

In the input-oriented model (Model 1), we assume that the main role of banks is to distribute funds between depositors and borrowers at the lowest costs. We therefore consider as inputs personnel expenses, interest expenses and other operating expenses, and as outputs net loans, total securities and other earning assets. We follow Hughes, Mester and Moon (2000) and assume that interest is an input (expense), which is consistent with the input minimization objective of Model 1. Total securities include equity investments by the banks while other earning assets include physical property and premises that are used in revenue generation like safekeeping transactions. The specification of Model 1 is as follows:

\footnotetext{
${ }^{1}$ The input-oriented model and the output oriented-model provide the same value of efficiency scores under CRS but not when assuming VRS.

${ }^{2}$ On the contrary, studies which consider bank branch efficiencies use the production approach.
} 
Model 1: DEA VRS Input-Oriented

$\operatorname{Min} \theta$

$$
\begin{array}{ll}
\text { s.t } & \\
\sum_{j=1}^{n} \lambda_{j} X_{i j} \leq \theta X_{i 0} & i=1,2, \ldots, m ; \\
\sum_{j=1}^{n} \lambda_{j} Y_{r j} \leq Y_{r 0} & \\
& \sum_{j=1}^{n} \lambda_{j}=1 \\
\lambda_{i} \geq 0 & j \in 1,2, \ldots, s ;
\end{array}
$$

where $\theta$ is the inefficiency score, $x_{i j}$ and $y_{i j}$ are the amount of the $i^{\text {th }}$ input consumed and the amount of the $r^{\text {th }}$ output generated by the $j^{\text {th }}$ bank, respectively. The index $n$ refers to number of bank observations, $m$ equals the three inputs (personnel expenses, interest expenses and other operating expenses) and $s$ refers to the three outputs (net loans, total securities and other earning assets).

As non-traditional bank activities, such as commission- and fee-based activities and trading activities have become more important, the exclusion of these items may bias efficiency measures (Berger and Mester, 1997). We use Model 2, which is an output maximization problem, to account for bank activity diversification. We follow Sturn and Williams $(2004,2006)$ and Avkirian $(1999,2000)$ by considering the interest expenses and the non interest expenses as inputs and the net interest income and the non interest income as outputs. Model 2 is specified as follows:

\section{Model 2: DEA VRS Output Oriented-Revenue Creation}

$$
\begin{aligned}
& \operatorname{Max}(1-\phi) \\
& \text { s.t } \quad \sum_{j=1}^{n} \lambda_{j} y_{r j} \leq(1-\phi) y_{r 0} \\
& \sum_{j=1}^{n} \lambda_{j} x_{i j} \leq x_{i 0} \quad r=1,2, \ldots, s \\
& \sum_{j=1}^{n} \lambda_{j}=1 \\
& \lambda_{i} \geq 0 \quad j \in 1,2, \ldots, n
\end{aligned}
$$

where is $(1-\phi)$ the efficiency score, $x_{i j}$ and $y_{i j}$ are the amount of the $i^{\text {th }}$ input consumed and the amount of the $r^{\text {th }}$ output generated by the $j^{\text {th }}$ bank, respectively. The index $n$ refers to 
number of bank observations, $m$ equals the two inputs (interest expenses and non interest expenses) and $s$ refers to the two outputs (net interest income and non interest income).

\subsection{Data}

The dataset used in this study contains observations from 1999 to 2004 on the population of commercial banks in Hong Kong, Indonesia, South Korea, Malaysia, Philippines and Thailand available in the Bankscope database which reports published financial statements from financial institutions worldwide. To maintain consistency across countries, only commercial banks are included in the analysis, which gives us 334 banks. We delete banks with less than five years of time series observations ${ }^{3}$. The final sample consists of 80 Asian banks (17 banks in Hong Kong, 12 banks in Indonesia, 13 banks in South Korea, 20 banks in Malaysia, 12 banks in the Philippines, and 6 banks in Thailand) yielding 358 bank-year observations (see Table A1 in the appendix for details on the distribution of the sample). In as much as we want a panel data approach to track possible technical changes or shifts in the frontier utilizing DEA, attrition reduces the number of cross-sections and to include only surviving banks might lead to survivor bias. The period 1999 to 2004 is chosen because the effect of the exogenous shocks to the region (Asian financial crisis) has passed and will no longer distort the estimates. If too short a period is chosen, inefficiency might not average out. If too long a period is chosen, the bank's efficiency score become less meaningful because of possible changes in management and other events. Berger and Mester (1997) concur with De Young (1997) that a six-year period reasonably balances the concerns of having too short or too long a period. The information for the country environmental level variables are sourced from the Asian Development Bank.

Table A2 provides some descriptive statistics of our dataset. Deposits are the main resource of the banks in our sample (75.62\%) and loans are their main assets $(53.12 \%)$. On average, interest income and non interest income represent respectively around 69\% and 29\% of their total income. Therefore, the banks in our sample include both traditional and nontraditional banking activities. The total capital ratio is equal to $16.53 \%$ on average showing that, on the whole, banks are well capitalized and have build up capital buffers over the period 1999 to 2004 . The level of non-performing loans differs significantly between countries. The ratio of non-performing loans to gross loans remains relatively high after the crisis period for

\footnotetext{
${ }^{3}$ This condition enables us to accurately compute the standard deviations of some variables.
} 
the Philippines, Malaysia and Thailand. Conversely, this same ratio is relatively low for Hong Kong, South Korea and Indonesia.

In our study, we code the ownership structure based on the stockholder information contained in the BankScope database. For banks with missing information, we have looked at the individual bank's websites to determine the appropriate classification. Majority ownership is defined as owning over 33\% of the stockholders' equity, following Laeven (1999). We consider a more detailed breakdown of bank ownership than in previous studies. We examine similar ownership forms as in Laeven (1999) but we also take institutional investors into account and hence consider five categories of ownership defined $a^{4}$ : (i) state-owned, shares being held by government institutions and corporations (9 banks); (ii) foreign-owned, shares being held by parent bank in foreign country or the bank being a foreign subsidiary (17 banks); (iii) private, shares being held by private companies as well as family-owned (35 banks); (iv) institutional investor-owned, shares being held by insurance companies and pension funds (11 banks); and, (v) widely-held, shares held by individual shareholders with stakes ranging from 5 to 33 percent ( 8 banks).

\subsection{Results}

Model 1 (Equation 1) and Model 2 (Equation 2) are used to calculate technical efficiency, denoted respectively TE1 and TE2 ${ }^{5}$. The technical efficiency scores we obtain are displayed in Table 1, as well as the technical efficiency scores from CRS (CRSTE1 and CRSTE2) and the technical efficiency scores from VRS (VRSTE1 and VRSTE2) used to calculate TE1 and $\mathrm{TE} 2^{6}$.

We use a Spearman rank test to compare the efficiency scores computed with Equation 1 and Equation 2. We find a Spearman correlation coefficient greater than 0.95. The null hypothesis of independency of each measure of efficiency is therefore rejected. In other words, banks with a higher level of efficiency obtained with Model 1 are also those exhibiting a higher level of efficiency with Model 2. We therefore do not find different results when computing efficiency scores with Model 1, which mainly considers traditional banking activities, and Model 2 which considers both traditional and non-traditional banking activities.

\footnotetext{
${ }^{4}$ Among the 80 banks in our sample, none was classified into two categories of ownership simultaneously. Otherwise, we would have deleted such banks from our sample.

${ }^{5}$ We use the DEAP Version 2.1 Computer Program by Tim Coelli to solve the linear programming problem.

${ }^{6} \mathrm{TE} 1$ is equal to the ratio of CSRTE1 to VRSTE1 and TE2 is equal to the ratio of CSRTE2 to VRSTE2.
} 
Table 1. Summary Statistics of Technical Efficiency scores computed with Equations 1 (DEA VRS Input-Oriented) and 2 (DEA VRS Output-Oriented Revenue Creation)

\begin{tabular}{|c|c|c|c|c|c|c|}
\hline & \multicolumn{3}{|c|}{ Equation 1 (Model 1) } & \multicolumn{3}{|c|}{ Equation 2 (Model 2) } \\
\hline & CRSTE1 & VRSTE 1 & TE1 & CRSTE2 & VRST & TE2 \\
\hline & \multicolumn{3}{|c|}{ Full Sample $(n=358)$} & \multicolumn{3}{|c|}{ Full Sample $(n=362)$} \\
\hline Mean & 0.3590 & 0.4546 & 0.7790 & 0.4468 & 0.5283 & 0.8446 \\
\hline Median & 0.2420 & 0.3585 & 0.8850 & 0.4250 & 0.5015 & 0.8815 \\
\hline Minimum & 0.0110 & 0.0410 & 0.0960 & 0.0620 & 0.0690 & 0.2760 \\
\hline \multirow[t]{2}{*}{ Std. Dev. } & 0.3029 & 0.3278 & 0.2457 & 0.1878 & 0.1935 & 0.1580 \\
\hline & \multicolumn{3}{|c|}{ Constant returns $(n=49)$} & \multicolumn{3}{|c|}{ Constant returns $(n=18)$} \\
\hline Mean & 0.7684 & 0.7685 & 0.9996 & 0.6255 & 0.6257 & 0.9998 \\
\hline Median & 1.0000 & 1.0000 & 1.0000 & 0.5380 & 0.5385 & 1.0000 \\
\hline Minimum & 0.0780 & 0.0790 & 0.9950 & 0.1490 & 0.1490 & 0.9990 \\
\hline \multirow[t]{2}{*}{ Std. Dev. } & 0.3499 & 0.3498 & 0.0010 & 0.3077 & 0.3076 & 0.0003 \\
\hline & \multicolumn{3}{|c|}{ Increasing returns $(n=220)$} & \multicolumn{3}{|c|}{ Increasing returns $(n=74)$} \\
\hline Mean & 0.2264 & 0.3294 & 0.7219 & 0.4718 & 0.5058 & 0.9394 \\
\hline Median & 0.1630 & 0.2570 & 0.8340 & 0.4765 & 0.4975 & 0.9815 \\
\hline Minimum & 0.0110 & 0.0410 & 0.0960 & 0.0990 & 0.1000 & 0.3540 \\
\hline \multirow[t]{2}{*}{ Std. Dev. } & 0.1695 & 0.2566 & 0.2702 & 0.1821 & 0.1963 & 0.1117 \\
\hline & \multicolumn{3}{|c|}{ Decreasing returns $(n=89)$} & \multicolumn{3}{|c|}{ Decreasing returns $(n=270)$} \\
\hline Mean & 0.4612 & 0.5911 & 0.7988 & 0.4280 & 0.5279 & 0.8083 \\
\hline Median & 0.4230 & 0.5590 & 0.8580 & 0.4105 & 0.4995 & 0.8160 \\
\hline Minimum & 0.0790 & 0.1300 & 0.2970 & 0.0620 & 0.0690 & 0.2760 \\
\hline Std. Dev. & 0.2481 & 0.3041 & 0.1663 & 0.1723 & 0.1818 & 0.1572 \\
\hline \multicolumn{7}{|c|}{ By country } \\
\hline Hong Kong & 0.3794 & 0.4797 & 0.7749 & 0.5474 & 0.6579 & 0.8405 \\
\hline Indonesia & 0.2703 & 0.3909 & 0.7143 & 0.3829 & 0.4933 & 0.7744 \\
\hline Korea & 0.5236 & 0.5709 & 0.9185 & 0.3374 & 0.4551 & 0.8610 \\
\hline Malaysia & 0.3641 & 0.4389 & 0.8240 & 0.5050 & 0.5566 & 0.9079 \\
\hline Philippines & 0.1545 & 0.2952 & 0.5880 & 0.4668 & 0.5067 & 0.7143 \\
\hline \multicolumn{7}{|c|}{ By year } \\
\hline 1999 & 0.3448 & 0.4484 & 0.7441 & 0.3595 & 0.4593 & 0.8037 \\
\hline 2000 & 0.5757 & 0.7039 & 0.8257 & 0.3759 & 0.4768 & 0.8008 \\
\hline 2001 & 0.3299 & 0.4150 & 0.7822 & 0.3966 & 0.4790 & 0.8264 \\
\hline 2002 & 0.2962 & 0.4261 & 0.7252 & 0.4664 & 0.5425 & 0.8572 \\
\hline 2003 & 0.3173 & 0.3746 & 0.8215 & 0.5168 & 0.5793 & 0.8904 \\
\hline 2004 & 0.3152 & 0.3867 & 0.7813 & 0.6251 & 0.6802 & 0.9182 \\
\hline
\end{tabular}

CRSTE $=$ constant returns to scale; VRSTE $=$ variable returns to scale; TE $=$ technical efficiency.

The literature distinguishes efficient banks as those exhibiting constant returns to scale and inefficient banks as those exhibiting variable (increasing and decreasing) returns to scale. The results highlight differences in the number of observations with increasing and decreasing returns to scale when we use an input oriented model (Model 1) or an output oriented model (Model 2). 
We find that 49 and 18 observations respectively exhibit constant returns to scale for Model 1 and Model 2; 220 observations exhibit increasing returns to scale for Model 1 whereas we only have 74 observations with increasing returns to scale when using Model 2; and 89 and 270 observations follow decreasing returns to scale respectively for Model 1 and for Model 2. The model specification is able to discriminate between efficient and inefficient banks as only 49 out of the 358 observations for the Model 1 and as only 18 out of 358 observations for Model 2, or $14 \%$ and $5 \%$ respectively are within the efficient frontier. Paradi, Vela and Yang (2005) note that when 25 to $50 \%$ of the sample lies on the frontier, it might become a problem for management to improve operations relative to other banks. Overall, the percentage of banks in the sample that are considered as technically inefficient is, on average, equal to 86 for Model 1 and 84 for Model 2. For the increasing returns group to reach the level of the efficient group, technical efficiency has to be improved by $28 \%$ if we consider Model 1(TE1) and 6\% if we consider Model 2 (TE2). Regarding the decreasing returns group, the level of efficiency has to be improved by around $20 \%$, whether we consider TE1 or TE2. The results also indicate that, during the post-crisis period, banks generally enjoy increasing returns when we consider Model 1 (with 220 out of 358 or $61.45 \%$ ), whereas we find that banks mainly face decreasing returns to scale when considering Model 2 (with 270 out of 358 or 75.45\%). Considering the pre-crisis period 1989-1996 for four ASEAN countries (Thailand, Malaysia, Indonesia and the Philippines), Karim (2001), using a parametric approach and considering only traditional activities, finds that on average ASEAN banks enjoy increasing returns to scale. Our results indicate therefore that Asian banks continue to benefit from increasing returns after the crisis period if we consider efficiency scores computed with Model 1, which includes only traditional banking activities. On the contrary, we find that Asian banks mainly face decreasing returns to scale in the post-crisis period when we include both traditional and non-traditional banking activities.

We further use the parametric and nonparametric tests of Banker (1993) to test if the efficient group (constant returns) is different from the inefficient group (increasing and decreasing returns). The non-parametric Kolmogorov-Smirnov (KS) test is applied as we maintain no assumptions on the probability distribution of inefficiency in equation 1 . The KS test statistic is given by the maximum vertical distance between $F^{G 1}\left(\ln \left(\hat{\theta}_{j}\right)\right)$ and $F^{G 2}\left(\ln \left(\hat{\theta}_{j}\right)\right)$, the empirical distributions of $\ln \left(\hat{\theta}_{j}\right)$ for groups $\mathrm{G}_{1}$ and $\mathrm{G}_{2}$, respectively. The KS test tries to determine if two datasets differ significantly, and the maximum difference between the 
cumulative distributions is given by the $D$ statistic. The $D$ statistic, by construction, takes values between 0 and 1 and a high value for this statistic is indicative of significant differences in inefficiency between two groups.

We find the $D$ statistic to be 0.9472 and 0.9797 respectively for TE1 (Model 1) and TE2 (Model 2), with a corresponding $p$ value of 0.000 , indicating a highly significant difference between the groups (see Table 2). To check for robustness, we also test the efficient group against the two inefficient subgroups separately, and find the $D$ statistics close to 1 with $\mathrm{p}$ values close to 0 for both Models 1 and 2, indicating highly significant differences in the efficiency scores.

Table 2. Comparison of returns to scale (TE1/TE2) between efficient and inefficient groups

\begin{tabular}{cc}
\hline Cumulative Distribution Score & $\begin{array}{c}\text { Null Hypothesis of } \\
\text { No Difference }\end{array}$ \\
\hline
\end{tabular}

Model 1 (TE1)

\begin{tabular}{l|l|l} 
CRS vs IRS and DRS & $D=0.9472 * * *$ & Rejected \\
CRS vs IRS & $D=0.9387 * *$ & Rejected \\
CRS vs DRS & $D=0.9775^{* * *}$ & Rejected
\end{tabular}

Model 2 (TE2)

\begin{tabular}{l|l|l} 
CRS vs IRS and DRS & $D=0.9797 * * *$ & Rejected
\end{tabular}

CRS vs IRS $\quad D=0.9324 * * * \quad$ Rejected

\begin{tabular}{l|l} 
CRS vs DRS & $D=0.9926^{* * *}$ \\
\hline
\end{tabular}

$* * *$ indicates significance at $p<0.01 . \mathrm{CRS}=$ constant returns to scale; IRS $=$ increasing return to scale ; and $\mathrm{DRS}=$ decreasing return to scale.

The KS test is a robust test that only focuses on the relative distribution of the data. Hence the value of the $D$ statistic is not affected by scale changes. In Figure 1 in the appendix, we can see that the KS percentile plot of the sets of efficiency scores is strikingly distinct. The efficient (CRS) scores plot are scrunched as a vertical line on the far right side of the graph while the inefficiency scores (IRS and DRS) appear as upwardly diagonal, indicating that on the whole, the efficiency scores are not likely to be normally nor log-normally distributed. ${ }^{7}$

We also check if technical efficiency scores are different across countries. We use the pair-wise KS test. In general, the results suggest that there exist differences in technical

\footnotetext{
${ }^{7}$ Percentile plot is a better estimate of the distribution function and the use of probability scales allows us to see how normal the data are. Normally distributed and log-normal data will plot as a straight line on probabilityscaled and probability-log scaled axes, respectively. The KS tests reported that the datasets on efficiency scores are unlikely to be normally or log normally (exponentially) distributed, hence the generality that the datasets are non-parametric and distribution free. This justifies the choice of the $D$ statistic over the Student's $t$ test in determining the differences between groups of banks.
} 
efficiency scores of banks across the six Asian countries under study (see Table 3). Indonesia and the Philippines reach the lowest average technical efficiency scores (Tables 2 and 3), both for Models 1 and 2. This result is consistent with Kwan's (2003) finding on Philippine banks exhibiting the highest per unit labor and per unit physical costs. South Korea averages the highest overall technical efficiency score for Model 1, while Thailand averages the highest overall technical efficiency score for Model 2. Relatively high and statistically significant difference is registered between South Korea and Indonesia $(D=0.4977)$, and South Korea and the Philippines $(D=0.5873)$ when we consider Model 1. For Model 2, we find strong significant differences between Indonesia and Thailand $(D=0.6257)$ as well as between South Korea and Thailand $(D=0.6232)$.

Table 3 Pair-wise KS Test for country differences in Efficiency scores

\begin{tabular}{lllllll}
\hline & Hong Kong & Indonesia & South-Korea & Malaysia & Philippines & Thailand \\
\hline Model 1 & & & & & & \\
Hong Kong & 1.000 & & & & & \\
Indonesia & 0.2198 & 1.000 & & & & \\
South-Korea & $0.3497^{* * *}$ & $0.4977^{* * *}$ & 1.000 & & & \\
Malaysia & 0.1927 & $0.3208^{* * *}$ & $0.2064^{*}$ & 1.000 & & \\
Philippines & $0.3649^{* * *}$ & $0.2583^{* *}$ & $0.5873^{* * *}$ & $0.4222^{* * *}$ & 1.000 & \\
Thailand & 0.1452 & $0.3118^{* *}$ & $0.2381^{* *}$ & 0.1215 & $0.4140^{* * *}$ & 1.000 \\
Model 2 & & & & & & \\
Hong Kong & 1.000 & & & & & \\
Indonesia & 0.2337 & 1.000 & & & & \\
South-Korea & $0.2493^{* *}$ & 0.1612 & 1.000 & & & \\
Malaysia & $0.3015^{* * *}$ & $0.4634^{* * *}$ & $0.5134^{* * *}$ & 1.000 & & \\
Philippines & $0.2700^{* *}$ & $0.4525^{* * *}$ & $0.4669^{* * *}$ & 0.0732 & 1.000 & \\
Thailand & $0.4296^{* * *}$ & $0.6257^{* * *}$ & $0.6232^{* * *}$ & 0.2513 & 0.2516 & 1.000 \\
\hline$* * * * * *$ indicate significance at $p<0.01, p<0.05$, and $p<0.10$, respectively. & &
\end{tabular}

We finally check if technical efficiency scores differ with ownership categories (Table 4). We use pair wise mean tests to compare technical efficiency scores between our five categories of owner ${ }^{8}$. When we consider technical efficiency scores computed with Model 1 (input minimization), we find that banks which are held by minority shareholders (widelyheld) exhibit higher levels of efficiency relatively to other banks across the Asian region during the period 1999-2004. We also find that foreign-owned banks have higher levels of efficiency if we consider Model 2 (revenue creation).

\footnotetext{
${ }^{8} \mathrm{We}$ are not able to use KS tests as previously because we do not have enough information for each category of ownership. The mean tests are available from the authors on request.
} 
Table 4. Technical efficiency and ownership structure

\begin{tabular}{|c|c|c|c|c|c|}
\hline & Foreign-owned & State-owned & Private-owned & $\begin{array}{c}\text { Institutional } \\
\text { investor-owned }\end{array}$ & Widely-held \\
\hline \multicolumn{6}{|c|}{ Model 1, TE1 } \\
\hline Mean & 0.856 & 0.847 & 0.842 & 0.846 & 0.918 \\
\hline Std & 0.073 & 0.061 & 0.069 & 0.064 & 0.068 \\
\hline Max & 0.961 & 0.963 & 0.956 & 0.939 & 0.980 \\
\hline Min & 0.714 & 0.758 & 0.697 & 0.748 & 0.776 \\
\hline \multicolumn{6}{|c|}{ Model 1, TE2 } \\
\hline Mean & 0.906 & 0.866 & 0.824 & 0.799 & 0.891 \\
\hline Std & 0.097 & 0.135 & 0.112 & 0.162 & 0.090 \\
\hline Max & 0.991 & 0.998 & 0.998 & 0.984 & 0.993 \\
\hline Min & 0.736 & 0.633 & 0.535 & 0.536 & 0.762 \\
\hline
\end{tabular}

To further investigate the relationship between bank efficiency and ownership, the efficiency scores generated from Equations 1 and 2 are used as dependent variables in multiple regressions to determine if bank characteristics and country-specific environmental variables can explain differences in efficiency.

\section{Determinants of efficiency scores}

\subsection{Regression analysis}

To investigate the factors that might explain differences in efficiency levels, we focus on the ownership structure of banks along with a number of control variables such as bank size, leverage and asset risk. Total assets is used as a proxy for bank size. We also introduce the ratio of equity to total assets to capture the quality of bank management and risk preferences. We expect a negative coefficient as well-capitalized banks reflect both a higher management quality and a higher aversion to risk taking. These banks should be more cost efficient in producing banking outputs. We further include the ratio of loan loss provisions to net loans as a proxy of output quality. The literature provides mixed results on the expected sign of the coefficient of this variable. The coefficient can be negative if banks spend more resources on credit underwriting and loan monitoring, and consequently fewer problem loans at the expense of higher operating costs (Mester, 1996). The coefficient of this variable can be positive if banks have high ratio of loan loss provisions to net loans, indicating poor loan 
quality that calls for higher operating costs related to credit risk and loan loss management (Berger and DeYoung, 1997).

We also consider another measure of output quality, which is the standard deviation of the return on assets (ROA). This broader measure of asset risk might be more appropriate for Model 1 where we consider as outputs not only net loans but also total securities and other earning assets. This measure of risk should also be applicable for Model 2 which accounts for traditional and non-traditional banking activities.

Regarding our ownership structure variables, we build five different dummy variables referring to the nature of ownership. We consider that there is a majority ownership when an owner holds at least $33 \%$ of the stockholders' equity. As the owners are classified in five categories, we create the following five dummy variables which takes the value of one when ownership is at least equal to $33 \%$ of the equity and 0 otherwise: state-owned, foreign-owned, private-owned, institutional investor-owned and widely-held. The different types of bank ownership refer to different forms of governance as discussed in Berger et al. (2005). Studies of U.S. corporations typically use the governance term to refer to the methods shareholders use to reduce managerial agency cost, such as board composition, voting rules, or stakes by managers. Ownership is assumed to be related to a bank's performance because the incentives for managers to efficiently allocate resources might differ under different ownership types or arrangements.

We then estimate the following cross-section equations to determine which factors are efficiency drivers:

$$
\text { Eff }_{\mathrm{i}}=\alpha \text { BankChar }_{\mathrm{i}}+\text { BOwnership }_{\mathrm{i}}+\eta_{\mathrm{i}}
$$

where the dependant variable Eff is the average efficiency score computed either with Model 1 or with Model 2. BankChar is the vector of bank characteristics and Ownership is the vector of ownership variables. $\alpha$ and $\beta$ are the coefficients of the estimates and $\eta$ is the disturbance term.

Because the efficiency scores generated by DEA models are dependant on each other, we use bootstrap estimators to calculate standard errors of our estimates (Xue and Harker, 1999; Casu and Molyneux, 2003). The DEA efficiency score is not an absolute efficiency index, but a relative efficiency score. The assumption of independence within the sample is therefore violated and conventional OLS is invalid. The results throughout this paper are obtained from 10000 bootstrap iterations. The estimation results are displayed in Table 5. 
Table 5: Determinants of Efficiency Scores (Bootstrap estimators)

\begin{tabular}{|c|c|c|c|c|}
\hline \multirow[b]{2}{*}{ Intercept } & \multicolumn{2}{|c|}{ TE1 } & \multicolumn{2}{|c|}{ TE2 } \\
\hline & $\begin{array}{l}0.859 * * * \\
(34.236)\end{array}$ & $\begin{array}{l}0.849 * * * \\
(34.798)\end{array}$ & $\begin{array}{l}0.810 * * * \\
(22.927)\end{array}$ & $\begin{array}{l}0.829 * * * \\
(17.584)\end{array}$ \\
\hline Total assets, average & $\begin{array}{c}0.0006^{*} \\
(1.672)\end{array}$ & $\begin{array}{c}0.0006^{*} \\
(1.689)\end{array}$ & $\begin{array}{r}-0.0005^{*} \\
(-1.990)\end{array}$ & $\begin{array}{r}-0.0005^{*} \\
(-1.807)\end{array}$ \\
\hline $\begin{array}{l}\text { Total equity/total assets, } \\
\text { average }\end{array}$ & $\begin{array}{l}-0.003^{*} \\
(-1.791)\end{array}$ & $\begin{array}{c}-0.002 \\
(-1.261)\end{array}$ & $\begin{array}{c}0.248 \\
(1.293)\end{array}$ & $\begin{array}{c}0.293 \\
(1.297)\end{array}$ \\
\hline $\begin{array}{l}\text { Loan loss provisions/net loans, } \\
\text { average }\end{array}$ & $\begin{array}{c}0.003 \\
(0.563)\end{array}$ & - & $\begin{array}{c}0.006 \\
(1.174)\end{array}$ & - \\
\hline Standard deviation of ROA & - & $\begin{array}{l}0.012^{*} \\
(1.723)\end{array}$ & - & $\begin{array}{l}-0.003 \\
(-0.536)\end{array}$ \\
\hline Foreign-owned & $\begin{array}{c}0.003 \\
(0.154)\end{array}$ & $\begin{array}{l}-0.005 \\
(0.018)\end{array}$ & $\begin{array}{l}0.071 * * \\
(2.271)\end{array}$ & $\begin{array}{c}0.092 * * * \\
(2.869)\end{array}$ \\
\hline Institutional investor owned & $\begin{array}{c}0.006 \\
(0.227)\end{array}$ & $\begin{array}{c}-0.003 \\
(-0.113)\end{array}$ & $\begin{array}{c}-0.042 \\
(-0.795)\end{array}$ & $\begin{array}{c}-0.052 \\
(-1.005)\end{array}$ \\
\hline State-owned & $\begin{array}{c}-0.011 \\
(-0.522)\end{array}$ & $\begin{array}{l}-0.011 \\
(-0.491)\end{array}$ & $\begin{array}{c}0.033 \\
(0.727)\end{array}$ & $\begin{array}{c}0.034 \\
(0.742)\end{array}$ \\
\hline Widely-held & $\begin{array}{c}0.077 * * * \\
(2.815)\end{array}$ & $\begin{array}{c}0.068 * * \\
(2.310)\end{array}$ & $\begin{array}{c}0.088 * * \\
(2.507)\end{array}$ & $\begin{array}{l}0.079 * \\
(1.885)\end{array}$ \\
\hline $\begin{array}{l}\text { Number of observations } \\
\mathrm{R}^{2}\end{array}$ & $\begin{array}{c}78 \\
0.2440\end{array}$ & $\begin{array}{c}71 \\
0.2956\end{array}$ & $\begin{array}{c}71 \\
0.2718\end{array}$ & $\begin{array}{c}63 \\
0.2912\end{array}$ \\
\hline
\end{tabular}

t-statistic in parentheses; $* * *, * *, *$ indicate significance at $p<0.01, p<0.05$, and $p<0.10$, respectively.

TE1 and TE2 are respectively technical efficiency from Model 1 (input minimization) and Model 2 (revenue model). Foreign-owned, Institutional investor-owned, State-owned, and Widely-held are dummy variables.

Regarding efficiency as measured in Model 1, we find that total assets, as a proxy for size, significantly and positively influences technical efficiency. Large banks are on average more efficient than smaller banks if we consider the input minimization model, which is consistent with Kwan (2006) and Drake et al. (2006). We also find a significant negative sign for the equity to total assets variable, but only at the $10 \%$ level. The coefficient associated with the ratio of loan loss provisions to net loans is not significant and therefore loan quality does not seem to alter efficiency. However, the coefficient of the broader measure of asset risk (standard deviation of ROA) is positive and significant, though at the $10 \%$ level only. Regarding the ownership structure variables, only the "widely-held" variable is significant and positively related to technical efficiency.

In the case of Model 2, bank size (total assets) has a negative significant coefficient. Unlike in Model 1, this result indicates that small banks are less efficient than large banks. In Model 2, inputs and output measures are revenue focused. It is therefore expected that Model 2 might yield different results because efficiency estimates are sensitive to input and output specification (Berger et al, 1993). The coefficient associated to the equity to total assets variable is not significant. As such, there appears to be no relationship between the degree of leverage and efficiency. We also find that the variable "foreign-owned" has a significant and 
positive impact on bank revenue creation efficiency. The results from Model 2 also confirm that banks which are held by minority private shareholders ("widely-held") have higher efficiency scores.

\subsection{Robustness checks and discussion of results}

We check the robustness of our results by considering environmental variables as determinants of efficiency scores. The objective of incorporating such variables is to associate variation in bank performance with variation in the exogenous variables characterizing the environment in which bank production and intermediation occurs. The exogenous variables influence performance not by influencing efficiency, with which they are assumed to be uncorrelated, but by influencing the structure of the technical and cost efficient frontier. Dietsch and Lozano-Vivas (2000) underline three categories of environmental variables that influence cost efficiency as a guide for cross-country studies: i) those that describe the main macroeconomic conditions which determine the banking product demand characteristics; ii) the variables that describe the structure and regulation of the banking industry, and; iii) those that characterize the accessibility of banking services.

In this study, we account for macroeconomic conditions by including the real GDP growth rate (GDP) as in Pastor (1999) ${ }^{9}$ which falls under the first category as prescribed by Dietsch and Lozano-Vivas (2000). We also introduce the difference between the loans and savings deposit interest rates (SPREAD) as a proxy for the structure and competition in the different national banking systems. A smaller gap between the loans and savings rates suggests a more competitive environment. Finally, we introduce the coefficient of variation of the country's exchange rate with respect to the US dollar (FOREX), which should capture the volatility of the local currency.

We find that environmental variables are on the whole not significant (see Table A3 in Appendix). The only significant variable is GDP with a positive influence on technical efficiency, when considering Model 1 (TE1) with the ratio of loan loss provisions to net loans taken as a proxy of output quality. Our results therefore highlight that the factors that influence efficiency do not depend on the economic environment. Regarding the ownership structure variables, our results remain the same. We find that the variable "foreign-owned" has a significant and positive impact on bank efficiency but only for revenue creation

\footnotetext{
${ }^{9}$ Pastor (1999) also introduces the use of unemployment rate and inflation rate as environmental variables. We do not use these two variables in our regressions as they are strongly correlated with the real GDP growth rate and the interest rate spread.
} 
efficiency (TE2), as previously. Our results also show that "widely-held" variable is significant and positively related to technical efficiency, but only at the $10 \%$ when considering TE2.

The results of our econometric investigation show that the differences in efficiency scores cannot be explained by the economic environment but can be explained by bank specific characteristics, namely ownership arrangements. We find that the relationship with size is positive and significant when we consider an input minimization objective (Model 1) and negative when we consider revenue creation (Model 2). We do not find a strong relationship between bank leverage and efficiency levels, and loan quality does not appear to determine efficiency levels. To a lesser extent, risk taking is a significant and positive driver of technical efficiency when an input minimization objective is considered.

Regarding the ownership structure, we find that banks which are held by minority shareholders exhibit higher levels of efficiency over the post-crisis period. This result is not consistent with the findings of Laeven (1999) showing that widely-owned banks experienced a decrease in efficiency relatively to other banks across the Asian region during the period 1992-1996. Based on the same ownership definition as proposed by Laeven (1999), our results highlight that for the post-crisis period, Asian banks which do not exhibit a concentrated ownership have higher efficiency levels. Therefore, our findings do not support the hypothesis of a positive impact of concentration on efficiency. We also find that foreignowned banks are more efficient than other domestic banks when we consider revenue creation. This is consistent with Laeven (1999) who highlights that foreign-banks showed an increase in efficiency relative to other banks.

\section{Conclusion}

The aim of this paper was to assess the implications of the restructuring process imposed on banking industries in Southeast Asia after the 1997 financial crisis. Within a regional approach involving six countries (Hong Kong, Indonesia, South Korea, Malaysia, Philippines and Thailand) we find that Asian banks generally benefit from increasing returns after the crisis period. However, we observe persistent differences in efficiencies across countries. Efficiency scores are relatively high for South Korea and relatively low for Thailand and the Philippines. The results of our econometric investigation show that such differences can be explained by bank specific characteristics. Efficiency is driven by bank 
size and to a lesser extent by risk taking. Our main findings, which are robust, are that banks owned by minority private shareholders and by foreign investors appear to be more efficient than other banks during the post-crisis period. Therefore, unlike some studies that report a positive effect of ownership concentration on efficiency in the same region during the precrisis period (Laeven (1999), our results suggest that reforms aiming to improve corporate governance might currently be beneficial to minority shareholders. Our second result regarding the role of foreign investors is consistent with previous studies. Hence, our findings imply that the entry and growing involvement of foreign investors is still beneficial for the efficiency of the banking industry in this region.

\section{References}

Avkiran, N. (2000) "Rising productivity of Australian trading banks under deregulation 19861995", Journal of Economics and Finance, 24, 122-140.

Avkiran, N. (1999) "The evidence on efficiency gains: the role of mergers and the benefits to the public", Journal of Banking \& Finance 23, 991-1013.

Banker, R.D. (1993) "Maximum Likelihood, Consistency and Data Envelopment Analysis: A Statistical Foundation," Management Science, October, 1265-1273.

Berger, A., Clarke G., Cull, R., Klapper, L. and Udell, G. (2005) "Corporate governance and bank performance: a joint analysis of the static, selection, and dynamic effects of domestic, foreign, and state ownership", Policy Research Working Paper \# 3632, The World Bank.

Berger, A. and D. Humphrey (1997) "Efficiency of financial institutions; International survey and directions for future research", European Journal of Operational Research, 98, 175-212.

Berger, A.N., and L.J. Mester (1997) "Inside the black box: What explains differences in the efficiencies of financial institutions?," Journal of Banking \& Finance 21, 895-947.

Berger, A., Humter, W., and S. Timme (1993) "The efficiency of financial of financial institutions: A review and preview of research past present and future", Journal of Banking and Finance, 17, 221-249.

Bonin, J.P., Hasan, I. and P. Wachtel (2005) "Bank performance, efficiency and ownership in transition countries", Journal of Banking and Finance, 29, 31-53.

Bos, J. and C. Kool (2006) "Bank efficiency; the role of bank strategy and local market conditions", Journal of Banking and Finance, 30(7), 1953-1974.

Casu, B and P. Molyneux (2003) “A Comparative Study of Efficiency in European Banking”, Applied Economics, 35(17), 1865-1875.

Charnes, A., W.W. Cooper, and E. Rhodes (1978) "Measuring the efficiency of decision-making units," European Journal of Operational Research, 429-444.

Choi, D.F. and W. Clovutivat (2004) "The relaxation of foreign ownership limits and market integration: The case of Thailand", Managerial Finance, 30, 78-89.

Claessens, S. Demirgüç-Kunt, A. and H. Huizinga (2001) "How does foreign entry affect domestic banking market?", Journal of Banking and Finance, 25, 891-911.

DeYoung, R. (1997) "A diagnostic test for the distribution-free efficiency estimator: An example using US commercial bank data", European Journal of Operational Research 98, 243-249. 
Dietsch, M. and A. Lozano-Vivas (2000) "How the environment determines banking efficiency: A comparison between French and Spanish industries". Journal of Banking \& Finance 24, 985-1004.

Drake, L., Hall, M. and M. Simper (2006) "The Impact of Macroeconomic and Regulatory Factors on Bank Efficiency : A Non-Parametric Analysis of Hong Kong's Financial Services Sector," Journal of Banking and Finance, 30, 1443-1466.

Fries, S. and A. Taci (2005) "Cost efficiency of banks in transition: Evidence from 289 banks in 15 post-communist countries", Journal of Banking and Finance, 29, 55-81.

Fries, S. and A. Taci (2002) "Banking reform and development in transition economics", $E B R D$, September.

Garcia, G. (1997) "A framework for analysis and assessment”, in Alexander, W.E., Davis, J.M., Ebrill, L.P., Lingren, C.J. (Eds), Systematic bank restructuring and macroeconomy policy, International Monetary Fund, Washington, DC.

Gelos, G. and J. Roldós (2004) "Consolidation and market structure in emerging market banking systems", Emerging Market Review, 5, 39-59.

Grigorian, D. and V. Manole(2002) "Determinants of commercial bank performance in transition: an application of Data Envelopment Analysis", World Bank Policy Research Working Paper 2850, June.

Hawkins, J. and D. Mihaljek (2001) "The banking industry in the emerging market economies: competition, consolidation and systemic stability - an overview", BIS Papers, 4.

Hawkins, J. and P. Turner (1999) "Bank restructuring in practice: an overview", BIS Policy Paper, 6.

Holderness, C.G. and D. Sheehan (1988) "The role of majority shareholders in publicly held corporations: an exploratory analysis", Journal of Financial Economics, 20, 317-347.

Hughes, J.P., L.M. Mester and C.G. Moon (2000) "Are scale economies in banking elusive or illusive? Evidence obtained by incorporating capital structure and risk-taking into models of bank production," Federal Reserve Bank of Philadelphia Working Paper No. 00-4, 44 pp.

Karim, M.Z.A. (2001) "Comparative bank efficiency across select ASEAN countries," ASEAN Economic Bulletin 18(3), 289-304.

Kwan, S.H. (2003) "Operating performance of banks among Asian economies: An international and time series comparison," Journal of Banking \& Finance 27, 471-489.

Kwan, S.H. (2006) "The X-Efficiency of Commercial Banks in Hong Kong," Journal of Banking \& Finance 30, 1127-1147.

Laeven, L. (1999) "Risk and efficiency in East Asian banks," World Bank Discussion Paper.

Paradi, J.C., S. Vela, and Z.Yang (2005) "Assessing Bank and Bank Branch Performance: Modeling Considerations and Approaches," in W.W. Cooper, L.M. Seiford, and J. Zhu, eds, Handbook on Data Envelopment Analysis, 349-400.

Pastor, J.M. (1999) "Efficiency and risk management in Spanish banking: a method to decompose risk," Applied Financial Economics 9, 371-384.

Schenk, C.R. (2002) "Banks and the emergence of Hong Kong as an international financial center," Journal of International Financial Markets, Institutions and Money, 12, 321340.

Sealey, C. and J. Lindley (1977) "Inputs, outputs, and theory of production cost and depository financial institutions", Journal of Finance, 32, 1251-1266.

Shleifer, A. and R. Vishny (1986) "Large shareholders and corporate control", Journal of Political Economy, 94, 461-488.

Shleifer, A. and R. Vishny (1997) "A survey of corporate governance", The Journal of Finance, 2, June. 
Sturm, J. and B. Williams (2006) "Characteristic determining the efficiency of foreign banks in Australia", mimeo.

Sturm, J. and B. Williams (2004) "Foreign bank entry, deregulation and bank efficiency: lesson from the Australian experience", Journal of Banking and Finance, 28, 17751799.

Unite, A. and M. Sullivan (2003) "The effect of foreign entry and ownership structure on the Philippine domestic banking market", Journal of Banking and Finance, 27(12), 23232345.

Williams, J., and N. Nguyen (2005) "Financial liberalization, crisis, and restructuring: A comparative study of bank performance and bank governance in South East Asia," Journal of Banking \& Finance 29, 2119-2154.

Xue, M., and P.T. Harker (1999) "Overcoming the Inherent Dependency of DEA Efficiency scores: A Boostrap Approach”, Working Paper 99-17, Financial Institution Center, Wharton School.

Yildrim, H.S. and G. Philippatos (2002) "Efficiency of Banks: Recent evidence from the transition economies of Europe", Mimeo, April. 


\section{APPENDIX}

Figure 1: KS-Test Comparison Percentile Plot (Model 1)

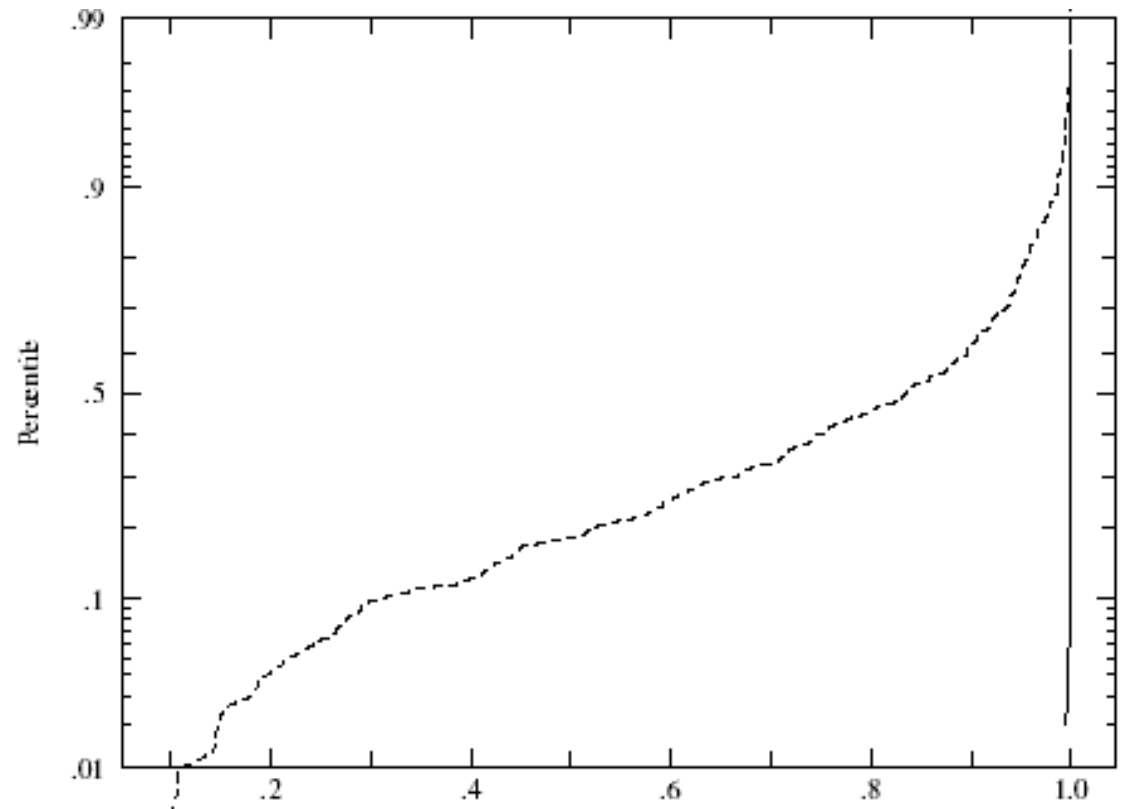

Table A1. Distribution of Sample (number of observations by country and by year)

\begin{tabular}{rcccrcrr}
\hline \hline & Hong Kong & Indonesia & South Korea & Malaysia & Philippines & Thailand & Total \\
\hline 1999 & 15 & 0 & 10 & 18 & 12 & 3 & 58 \\
2000 & 11 & 0 & 13 & 15 & 11 & 4 & 54 \\
2001 & 8 & 12 & 12 & 16 & 11 & 6 & 65 \\
2002 & 8 & 12 & 12 & 15 & 10 & 6 & 63 \\
2003 & 8 & 12 & 12 & 13 & 9 & 6 & 60 \\
2004 & 8 & 12 & 12 & 13 & 7 & 6 & 58 \\
Total & 58 & 48 & 71 & 90 & 60 & 31 & \\
358 & & & & & & &
\end{tabular}


Table A2. Descriptive Statistics for the Panel of 80 Asian Commercial Banks, on average over the period 1999-2004

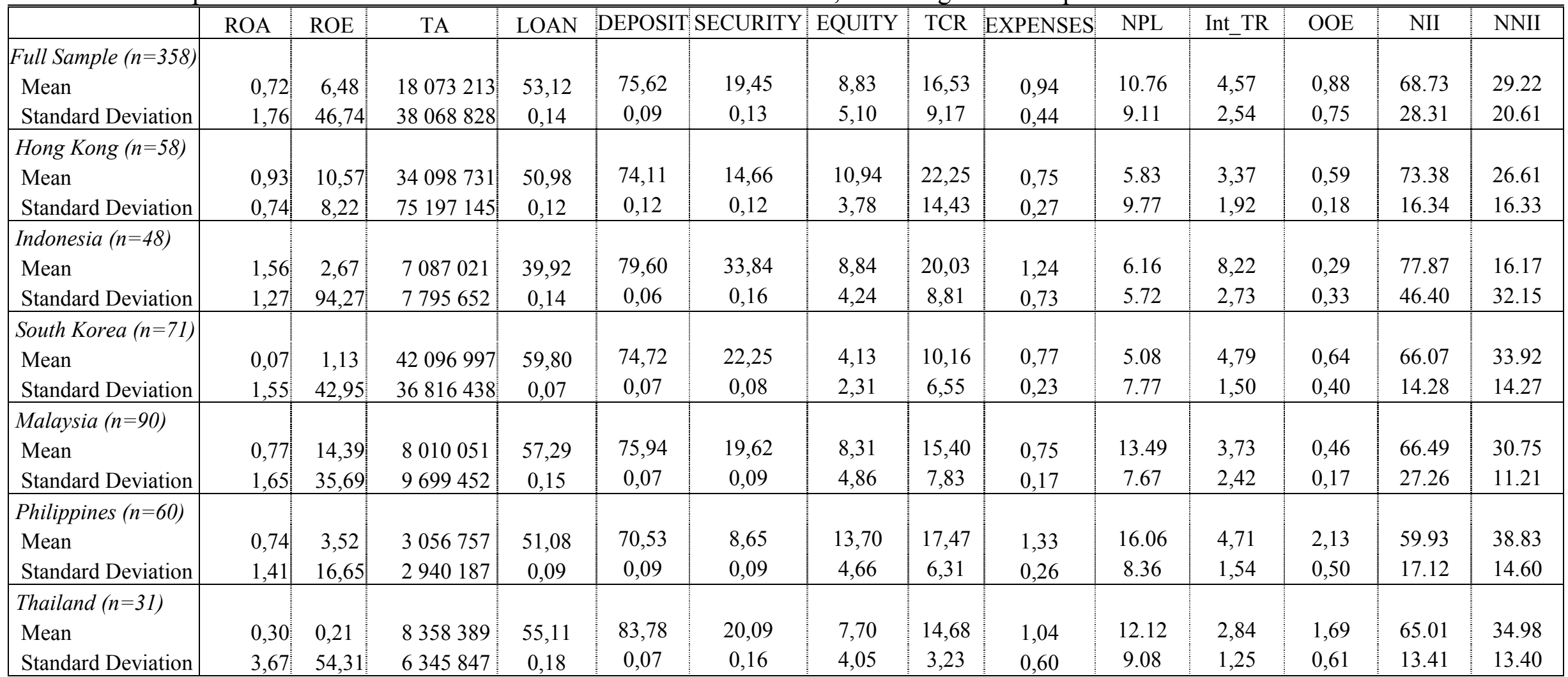

Variable definitions (all ratios are expressed in percentages): ROA = return on average assets; ROE = return on average equity; TA : total assets in millions of US dollars; LOANS = net loans/total assets; DEPOSIT = deposits/total assets; SECURITY= securities /Total assets; EQUITY = equity/total assets; TCR = Total capital ratio; EXPENSES = personnel expenses/total assets; NPL = non performing loans/gross loans; Int TR = interest expenses/total resources; OOE = operating expenses/Total assets; $N I I=$ net interest income/net operating income; $N N I I=$ net non interest income/ net operating income. 
Table A3: Regression of Efficiency Scores with ownership structure and environmental variables (Bootstrap estimators)

\begin{tabular}{|c|c|c|c|c|}
\hline & \multicolumn{2}{|c|}{ TE1 } & \multicolumn{2}{|c|}{ TE2 } \\
\hline Intercept & $\begin{array}{c}0.662 * * * \\
(6.373)\end{array}$ & $\begin{array}{l}0.715 * * * \\
(6.113)\end{array}$ & $\begin{array}{c}0.601 * * * \\
(3.204)\end{array}$ & $\begin{array}{c}0.763 * * * \\
(3.458)\end{array}$ \\
\hline Total assets, average & $\begin{array}{c}0.0006^{*} \\
(1.917)\end{array}$ & $\begin{array}{l}0.0001 * \\
(1.702)\end{array}$ & $\begin{array}{l}-0.0005 \\
(-1.501)\end{array}$ & $\begin{array}{l}-0.0002 \\
(-1.492)\end{array}$ \\
\hline $\begin{array}{l}\text { Total equity/total assets, } \\
\text { average }\end{array}$ & $\begin{array}{l}-0.002 \\
(-0.960)\end{array}$ & $\begin{array}{c}-0.002 \\
(-0.838)\end{array}$ & $\begin{array}{c}0.336 \\
(1.593)\end{array}$ & $\begin{array}{c}0.305 \\
(1.150)\end{array}$ \\
\hline $\begin{array}{l}\text { Loan loss provisions/net loans, } \\
\text { average }\end{array}$ & $\begin{array}{c}-0.000 \\
(-0.009)\end{array}$ & - & $\begin{array}{c}0.006 \\
(1.193)\end{array}$ & - \\
\hline Standard deviation of ROA & - & $\begin{array}{c}0.010 \\
(1.471)\end{array}$ & - & $\begin{array}{c}-0.004 \\
(-0.554)\end{array}$ \\
\hline Foreign-owned & $\begin{array}{c}-0.00 \\
(-0.211)\end{array}$ & $\begin{array}{c}-0.005 \\
(-0.263)\end{array}$ & $\begin{array}{l}0.064^{*} \\
(1.905)\end{array}$ & $\begin{array}{c}0.093 * * * \\
(2.833)\end{array}$ \\
\hline Institutional investor owned & $\begin{array}{l}-0.007 \\
(-0.227)\end{array}$ & $\begin{array}{c}-0.010 \\
(-0.369)\end{array}$ & $\begin{array}{l}-0.499 \\
(-0.775)\end{array}$ & $\begin{array}{c}-0.044 \\
(-0.760)\end{array}$ \\
\hline State-owned & $\begin{array}{l}-0.027 \\
(-1.176)\end{array}$ & $\begin{array}{c}-0.020 \\
(-0.842)\end{array}$ & $\begin{array}{c}0.038 \\
(0.780)\end{array}$ & $\begin{array}{c}0.038 \\
(0.815)\end{array}$ \\
\hline Widely-held & $\begin{array}{l}0.063 * * * \\
(2.230)\end{array}$ & $\begin{array}{l}0.060 * * \\
(1.961)\end{array}$ & $\begin{array}{l}0.085^{*} \\
(1.914)\end{array}$ & $\begin{array}{l}0.082 * \\
(1.847)\end{array}$ \\
\hline GDP & $\begin{array}{l}0.031 * * \\
(1.977)\end{array}$ & $\begin{array}{c}0.020 \\
(1.128)\end{array}$ & $\begin{array}{c}0.033 \\
(1.073)\end{array}$ & $\begin{array}{c}0.008 \\
(0.244)\end{array}$ \\
\hline FOREX & $\begin{array}{c}0.509 \\
(2.463)\end{array}$ & $\begin{array}{c}0.302 \\
(1.316)\end{array}$ & $\begin{array}{c}0.156 \\
(0.411)\end{array}$ & $\begin{array}{c}0.005 \\
(0.013)\end{array}$ \\
\hline SPREAD & $\begin{array}{c}0.004 \\
(1.081) \\
\end{array}$ & $\begin{array}{c}0.003 \\
(0.848) \\
\end{array}$ & $\begin{array}{c}0.006 \\
(0.872) \\
\end{array}$ & $\begin{array}{c}0.004 \\
(0.534) \\
\end{array}$ \\
\hline $\begin{array}{l}\text { Number of observations } \\
\mathrm{R}^{2}\end{array}$ & $\begin{array}{c}71 \\
0.3169 \\
\end{array}$ & $\begin{array}{c}71 \\
0.3248 \\
\end{array}$ & $\begin{array}{c}63 \\
0.2842 \\
\end{array}$ & $\begin{array}{c}63 \\
0.3025 \\
\end{array}$ \\
\hline
\end{tabular}

t-statistic in parentheses; $* * *, * *, *$ indicate significance at $p<0.01, p<0.05$, and $p<0.10$, respectively.

TE1 and TE2 are respectively technical efficiency from model 1 (input minimization) and model 2

(revenue model). Foreign-owned, institutional investor-owned, state-owned, and widely-held are dummy variables. GDP= real GDP growth rate; FOREX = coefficient of variation of the country's exhange rate measured in US dollars; SPREAD = difference between loan and saving deposit interest rate. 